\title{
Microbial dynamics in coastal waters of East Antarctica: bacterial production and nanoflagellate bacterivory
}

\author{
Raymond J. G. Leakey*, Stephen D. Archer, Jonathan Grey \\ British Antarctic Survey, High Cross, Madingley Road, Cambridge CB3 0ET, United Kingdom \\ In collaboration with the Australian Antarctic Division, Channel Highway, Kingston, Tasmania 7050, Australia
}

\begin{abstract}
Bacterial production and heterotrophic nanoflagellate (HNAN) bacterivory were determined concurrently with measurements of abundance and biomass at weekly intervals between 30 December 1993 and 11 February 1994 at a shallow, coastal location in Prydz Bay, eastern Antarctica. Bacterial production was measured by $\left[{ }^{3} \mathrm{H}\right]$ thymidine incorporation and HNAN bacterivory by the uptake of fluorescently labelled bacteria. Bacterial abundance, biomass and production ranged from 2 to $8 \times 10^{8} \mathrm{l}^{-1}, 13$ to $64 \mu \mathrm{g} \mathrm{C} \mathrm{l^{-1 }}$ and 8 to $14 \mu \mathrm{g} \mathrm{C} \mathrm{l}^{-1} \mathrm{~d}^{-1}$, respectively, with maximum values recorded in mid January. The HNAN community comprised choanoflagellate, non-collared and colonial taxa, with non-collared forms dominating abundance and biomass in late January and early February. Total HNAN abundance and biomass ranged from 1.6 to $4.2 \times 10^{6} \mathrm{I}^{-1}$ and 8 to $16 \mu \mathrm{g} \mathrm{Cl}^{-1}$, respectively. HNAN cellular ingestion and clearance rates differed between taxa with maximum rates of 8.28 particles cell-1 $\mathrm{h}^{-1}$ and $9.32 \mathrm{nl}$ cell $^{-1} \mathrm{~h}^{-1}$ recorded for large non-collared forms. During the study period the HNAN community grazed 0.9 to $4.7 \mu \mathrm{g}$ bacterial $\mathrm{Cl}^{-1} \mathrm{~d}^{-1}$, equivalent to 3 and $12 \%$ of bacterial biomass, and 10 and $36 \%$ of daily bacterial production; however, these values are likely to be minimal estimates and grazing impact may have been higher on occasion. Choanoflagellates were responsible for much of the grazing impact at the beginning of the study penod, while non-collared HNAN were the domınant grazers in late January and early February. The HNAN community therefore appears to graze substantial bacterial production in Antarctic coastal waters during the austral summer, although alternative sources of bacterial mortality are likely to be of importance.
\end{abstract}

KEY WORDS: Flagellates - Bacteria - Grazing Production Antarctic

\section{INTRODUCTION}

The importance of heterotrophic microbial processes to the structure and functioning of marine planktonic ecosystems is now well established (Azam et al. 1983, Fenchel 1988). Bacterioplankton populations are abundant and productive across a range of environments and may consume up to $60 \%$ of primary production via dissolved organic matter (Cole et al. 1988, Ducklow \& Carlson 1992, Simon et al. 1992). The magnitude of this bacterial production and its significance to planktonic carbon and energy flow has given rise to considerable interest in the factors controlling and limiting the growth and mortality of bacterial populations (Billen et al. 1990, Berninger et al. 1991b, Ducklow 1992 ,

•E-mail: r.leakey@bas.ac.uk
Sanders et al. 1992, Gasol \& Vaques 1993, Pace \& Cole 1994). Amongst the latter, grazing by heterotrophic nanoflagellate protists (HNAN) is considered to be a major loss process, and can often balance bacterial production (Pace 1988, Berninger et al. 1991a, Sherr \& Sherr 1994); however, bacterivory by other protists and viral-induced lysis may also be significant (Sherr \& Sherr 1994, Fuhrman \& Nobel 1995).

Although the majority of studies investigating marine planktonic microbial communities have focused on temperate water environments, abundant bacterial and HNAN populations have been observed in both coastal and oceanic Antarctic environments, suggesting that the structure and function of microheterotrophic communities may be similar in both temperate and polar environments (Garrison \& Gowing 1993, Karl 1993). Bacterial activity in Antarctic waters can also be signif- 
icant, at least during summer months, with production values of up to $17 \mu \mathrm{g} \mathrm{Cl}^{-1} \mathrm{~d}^{-1}$ (Ducklow \& Carlson 1992, Karl 1993). However, information on protist grazing rates from polar waters are rare and to date no measurements of HNAN bacterivory have been undertaken concurrently with estimates of bacterial production. The importance of HNAN in controlling and limiting bacterial production in these cold and highiy seasonal environments therefore has to be assessed.

The aim of this study was to determine the grazing impact of the HNAN community on bacterioplankton during summer months at a shallow water coastal location in Prydz Bay, eastern Antarctica. The coastal waters of Prydz Bay are characterised by an annual cycle of sea ice formation and melt, and a distinct annual cycle of plankton biomass dominated in summer by high numbers of the colonial flagellate Phaeocystis sp. (Davidson \& Marchant 1992). Previous studies in the locality have documented the taxonomic composition and abundance of components of the planktonic microbial community, including bacteria and HNAN (Marchant 1985, Perrin et al. 1987, Gibson et al. 1990, Marchant \& Perrin 1990, Davidson \& Marchant 1992). The present study formed part of a coordinated programme to measure microbial productivity and estimate the importance of heterotrophic protists to carbon-energy flow in Antarctic coastal waters. Associated studies were undertaken on the net microbial production (C. Robinson et al. unpubl.), ciliate herbivory (J. Grey \& R. J. G. Leakey unpubl.) and dinoflagellate herbivory (Archer et al. 1996). In this study, HNAN grazing rates were determined from the uptake of fluorescently labelled bacteria (FLB) concurrently with measurements of bacterial production by radioactive thymidine incorporation

\section{MATERIALS AND METHODS}

Study site. Seven experiments were undertaken at approximately weekly intervals from 30 December 1993 to 11 February 1994 during ice-free conditions at a site approximately $1 \mathrm{~km}$ offshore from the Australian Antarctic station of Davis (68 $34.5^{\prime} \mathrm{S}, 77^{\circ} 58.0^{\prime} \mathrm{E}$; Fig. 1). The sample site had a water depth of approximately $22 \mathrm{~m}$.

Preparation of FLB. FLB were prepared from natural bacterioplankton (Sherr \& Sherr 1993). Three to four days prior to each experiment, $6 \mathrm{l}$ of water was collected from $5 \mathrm{~m}$ depth using an acid-cleaned $2.5 \mathrm{l}$ GoFlo water bottle. On return to the laboratory, the natural bacterioplankton population $\left(2\right.$ to $6 \times 10^{5}$ cells $\mathrm{ml}^{-1}$ ) was screened through a $10 \mu \mathrm{m}$ mesh to remove large particulates, concentrated by centrifugation at

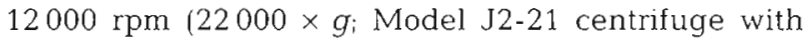
JA14 rotor, Beckman Instruments, Fullerton, CA, USA), resuspended in $10 \mathrm{ml} 0.02 \mathrm{M}$ tris buffer, and incubated with $0.2 \mathrm{mg} \mathrm{ml}^{-1} 5$-(4,6-dichlorotriazin-2-yl) aminofluorescein (DTAF) for $1 \mathrm{~h}$ at 50 to $60^{\circ} \mathrm{C}$. The FLB were then washed 3 times with $0.02 \mathrm{M}$ tris buffer,

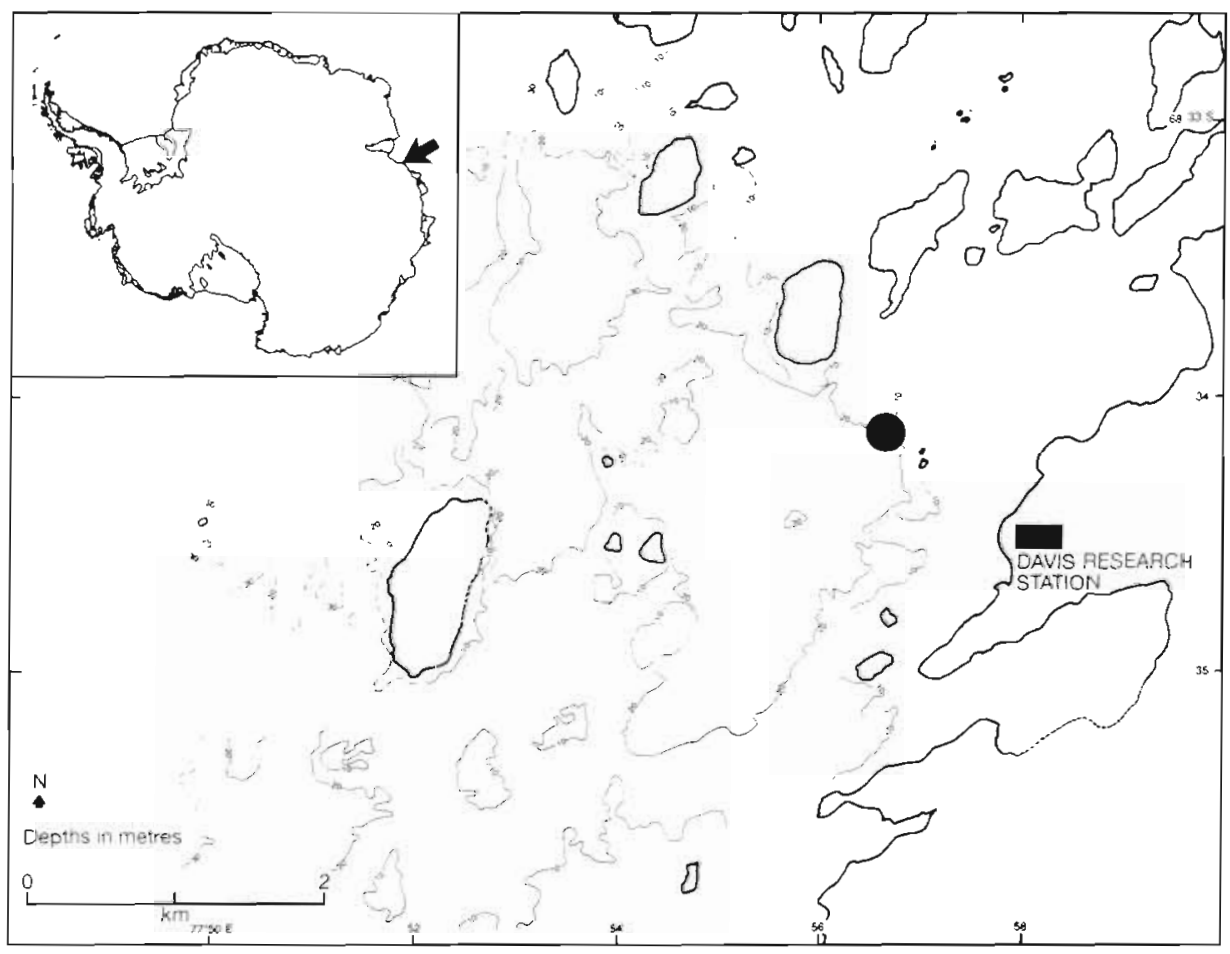

Fig. 1 Study area showing the location of the sampling site (in the vicinity of the Australian Antarctic station of Davis 
screened through a $2.0 \mu \mathrm{m}$ polycarbonate filter to remove clumps and stored frozen at $-20^{\circ} \mathrm{C}$. Final FLB concentrations ranged from 3 to $6 \times 10^{7}$ cells $\mathrm{ml}^{-1}$, a concentration factor of 80 to 252 times that of the natural bacterial population.

Experimental procedure. For each experiment, measurements of water temperature and salinity were made at $5 \mathrm{~m}$ depth using a Platypus CTD. Three replicate 2.51 Go-Flo water bottle samples were then collected from $5 \mathrm{~m}$ depth for the determination of chlorophyll a (chl a) concentration, HNAN bacterivory and bacterial production, as outlined below. All polycarbonate incubation bottles and tubes were cleaned by soaking for $24 \mathrm{~h}$ in $10 \% \mathrm{HCl}$, rinsed several times with deionised water, autoclaved and rinsed with experimental seawater immediately prior to use. Experimental water was, at all times, maintained at ambient water temperature by storing in an insulated box filled with water from $5 \mathrm{~m}$ depth, or by incubating in situ at $5 \mathrm{~m}$ depth. All samples were stored cool and in the dark until processed.

Chl a concentration: Three replicate 1 l samples were returned to the laboratory and each filtered at a vacuum pressure of $10 \mathrm{~mm} \mathrm{Hg}$ onto a $47 \mathrm{~mm}$ diameter $\mathrm{GF} / \mathrm{F}$ filter. Each filter was then stored frozen at $-20^{\circ} \mathrm{C}$ for subsequent spectrophotometric analysis of chl a concentration, according to Talling (1974).

HNAN bacterivory: Approximately 30 min after sampling (to enable HNAN to recover from handling shock), $1 \mathrm{ml}$ of the FLB stock was added to each of 3 replicate $450 \mathrm{ml}$ samples. Each sample was gently mixed and a $50 \mathrm{ml} t_{\text {zero }}$ sub-sample removed immediately and fixed with $1 \%$ final concentration ice-cold glutaraldehyde. The samples were then incubated in situ for after 10,20, 40 and $80 \mathrm{~min}$ and $50 \mathrm{ml}$ subsamples were removed and fixed at each of these times. On return to the laboratory, $10 \mathrm{ml}$ of each subsample were stained for 5 min with $5 \mu \mathrm{g} \mathrm{ml} \mathrm{ml}^{-1} 4^{\prime} 6$ diamidino-2-phenylindole (DAPI), filtered onto a standard $2 \mu \mathrm{m}, 25 \mathrm{~mm}$ diameter polycarbonate filter (with $0.2 \mu \mathrm{m}$ cellulose nitrate backing filter), washed with $0.2 \mu \mathrm{m}$ filtered deionised water, mounted on a slide and stored frozen at $-20^{\circ} \mathrm{C}$ prior to analysis. The subsamples were observed at $1250 \times$ magnification using a Leitz Labolux $\mathrm{S}$ epifluorescence microscope equipped with 12 (blue excitation) and A (UV excitation) filter blocks. Nanoflagellates were identified by their blue fluorescence observed under UV-light illumination, and heterotrophs distinguished from autotrophs by the absence of chl a autofluorescence observed under blue-light illumination. HNAN were grouped into taxonomic categories based on size, shape and morphology. Choanoflagellates were identified by the presence of a collar of tentacles surrounding the flagellum (Buck et al. 1991). Dinoflagellates, distinguishable by their cell morphology and, in particular, by their unique condensed chromosomes visible by DAPI staining (Verity et al. 1993), were not included in the analysis.

The abundance of each HNAN type was determined from 50 fields of view on each replicate filter from the $t_{\text {zero }}$ treatments. The linear dimensions and volumes of 30 cells of each taxon from 1 filter were measured by image analysis using a Sony CMCCD camera connected to a Seescan Solitaire Plus system. A high-pass filter facility was used to enhance cell images and the area of each cell was then delineated manually. Cell volume was calculated from cell area and perimeter measurements according to Fry \& Davies (1985). HNAN population volume was calculated by multiplying mean cell volume by abundance. Population volume was converted to carbon biomass using a conversion factor of $0.22 \mathrm{pg} \mathrm{mm}^{-3}$ (Børsheim \& Bratbak 1987).

To determine HNAN bacterivory up to 100 cells of each taxon were observed for each replicate filter from all treatments and the number of FLB ingested by each cell determined under blue-light illumination. Ingested FLB of different sizes could be clearly distinguished within the same focal plane as the flagellates; however, HNAN within $t_{\text {zero }}$ treatments were also examined to account for any FLB appearing to be ingested but lying on or below cells. HNAN cellular ingestion rate on bacterial-sized particles [(FLB + bacteria) $\mathrm{HNAN}^{-1} \mathrm{~h}^{-1}$ ] was then calculated by dividing mean FLB uptake (FLB $\mathrm{HNAN}^{-1} \mathrm{~h}^{-1}$ ) by FLB specific activity (i.e. FLB concentration divided by the total concentration of FLB + bacteria, determined as outlined below). Cellular clearance rate ( $\mathrm{nl} \mathrm{HNAN}^{-1} \mathrm{~h}^{-1}$ ) was determined by dividing the ingestion rate by the concentration of FLB + bacteria (McManus \& Fuhrman 1988a). Volume specific clearance rate was calculated from clearance rate divided by cell volume. The population clearance rate of each HNAN taxon ( $\left.\mu l^{-1} \mathrm{~d}^{-1}\right)$ was calculated from cellular clearance rate multiplied by HNAN abundance. Bacterial biomass removed by each HNAN

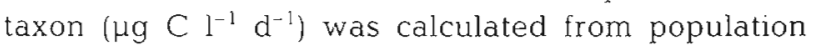
clearance rate using bacterial biomass values determined as outlined below.

To determine bacterial abundance, $5 \mathrm{ml}$ of each replicate $t_{\text {zero }}$ sub-sample were stained with $5 \mu \mathrm{g} \mathrm{ml}^{-1}$ DAPI, filtered onto a black $0.2 \mu \mathrm{m}, 25 \mathrm{~mm}$ diameter polycarbonate filter, mounted on a slide and observed under UV-light illumination. Bacteria were identified by their blue fluorescence and enumerated from 25 fields of view on each filter. To determine bacterial cell volume, the volumes of 30 cells from 1 filter were measured by image analysis as outlined above but using an auto/interactive threshold function to delineate cell areas. FLB concentration and cell volume were similarly determined by concentrating a further $5 \mathrm{ml}$ 
from each replicate $t_{z e r o}$ treatment onto a standard 0.2 $\mu \mathrm{m}, 25 \mathrm{~mm}$ diameter polycarbonate filter and observing their yellow/green fluorescence under blue-light illumination. Bacterial population volume was calculated from abundance and cell volume estimates, and converted to carbon biomass using a conversion factor of $0.22 \mathrm{pg} \mathrm{m}^{-3}$ (Bratbak \& Dundas 1984). To compare biomass estimates derived from cell volumes measured by image analysis or by calibrated ocular micrometer, bacterial biomass was also calculated by grouping cells into 4 size categories: 0.5 to $1 \mu \mathrm{m}$ diameter cocci, and 0.5 to 1,1 to 2 and 2 to $4 \mu \mathrm{m}$ length rods.

Bacterial production: Bacterial production was determined from [ ${ }^{3} \mathrm{H}$ ]thymidine incorporation (Fuhrman \& Azam 1980, Bell 1993). A total of $450 \mu$ of an aqueous stock solution of $\left[{ }^{3} \mathrm{H}\right.$-methyl]thymidine $(42$ to $44 \mathrm{Ci}$ $\mathrm{mmol}^{-1}$ ) was added to each of 3 replicate $22.5 \mathrm{ml}$ samples to give an estimated $10 \mathrm{nM}$ final concentration, and the contents mixed. A $t_{\text {zero }} 10 \mathrm{ml}$ sub-sample was immediately removed and fixed with $1 \%$ final concentration formaldehyde. The remaining $13 \mathrm{ml}$ were then incubated in situ at $5 \mathrm{~m}$ depth for $4 \mathrm{~h}$ after which a further $10 \mathrm{ml}$ sub-sample was removed and fixed. A control sample, poisoned with formaldehyde prior to adding $\left[{ }^{3} \mathrm{H}\right]$ thymidine, was incubated concurrently. Each subsample was returned to the laboratory, filtered onto a $0.2 \mu \mathrm{m}, 25 \mathrm{~mm}$ diameter polycarbonate filter, rinsed with $0.2 \mu \mathrm{m}$ filtered autoclaved seawater, extracted with $2 \times$ $10 \mathrm{ml}$ ice-cold $5 \%$ TCA for at least $10 \mathrm{~min}$, and finally rinsed with $80 \%$ ethanol. Each filter was then placed in a scintillation vial and mixed with $10 \mathrm{ml}$ scintillation fluid (Optiphase HiSafe II, Wallac UK, Milton Keynes). After $12 \mathrm{~h}$, radioactivity in the sub-samples was measured using a Wallac LKB Rackbeta II (type 1215) liquid scintillation counter and the efficiency of counting determined by the external standard channels ratio method. $\left[{ }^{3} \mathrm{H}\right]$ thymidine incorporation was calculated from counts (corrected for quenching and blanks) according to Bell (1993) using isotope specific activity values corrected for decay (Stewart \& Hawcroft 1977).

To confirm linear incorporation of $\left[{ }^{3} \mathrm{H}\right]$ thymidine during in situ incubation, a time course experiment was undertaken on 11 February 1994 using water from the 3 replicate experimental water bottle samples collected on that date. $\left[{ }^{3} \mathrm{H}\right]$ thymidine was added to replicate $40 \mathrm{ml}$ samples to produce a final concentration of $10 \mathrm{nM}$. A $10 \mathrm{ml}$ sub-sample was immediately removed and fixed, and the remaining sample incubated in situ for 2, 4 and $6 \mathrm{~h}$ after which further $10 \mathrm{ml}$ sub-samples were removed and fixed. All sub-samples were then processed as above. Incorporation of $\left[{ }^{3} \mathrm{H}\right]$ thymidine was proportional to incubation time during the $6 \mathrm{~h}$ incubation (regression: $\mathrm{r}^{2}=0.904_{i} \mathrm{p}<$ 0.001 ) confirming the appropriate choice of a $4 \mathrm{~h}$ incubation time for the bacterial production experiments.
To empirically determine a $\left[{ }^{3} \mathrm{H}\right]$ thymidine conversion factor relating incorporation of isotope to bacterial growth, a calibration experiment was undertaken on 13 February 1994 following the methodology of Kirchman \& Ducklow (1993). Water (2 1) was collected from $5 \mathrm{~m}$ depth and $45 \mathrm{ml}$ diluted $1: 9$ with $0.22 \mu \mathrm{m}$ filtered water from the same source. Three replicate $20 \mathrm{ml} \mathrm{sub-}$ samples were removed and fixed with $1 \%$ final concentration glutaraldehyde for subsequent enumeration of bacterial abundance and cell volume, as outlined above. At the same time, a further three $20 \mathrm{ml}$ replicate sub-samples were removed for the in situ determination of $\left[{ }^{3} \mathrm{H}\right]$ thymidine incorporation over $4 \mathrm{~h}$, as outlined above. The remaining $380 \mathrm{ml}$ sample was then incubated in situ for $24 \mathrm{~h}$ after which sub-samples were removed for bacterial enumeration and $\left[{ }^{3} \mathrm{H}\right]$ thymidine incorporation as before. No significant difference ( $t$-test; $p=0.72$ ) was observed between the cell volumes of bacteria recorded initially (mean = $0.327 \mu^{3}$ ) and after $24 \mathrm{~h}$ incubation (mean $=0.312 \mu \mathrm{m}^{3}$ ). A $\left[{ }^{3} \mathrm{H}\right]$ thymidine conversion factor of $1.91 \times 10^{18}$ cells $\mathrm{mol}^{-1}$ was calculated from bacterial abundance and isotope incorporation rate using the integrative approach (Kirchman \& Ducklow 1993). This value was used to calculate bacterial population growth (cells $1^{-1}$ $\left.\mathrm{d}^{-1}\right)$ from $\left[{ }^{3} \mathrm{H}\right]$ thymidine incorporation for each experiment. Bacterial production was then calculated from growth using the mean cell carbon content estimated for each experiment, as outlined above.

To check the $\left[{ }^{3} \mathrm{H}\right]$ thymidine concentration in experimental samples, a $100 \mu$ l aliquot was removed from each $t_{\text {zero }}$ sub-sample before filtration, added to a scintillation vial, mixed with $1 \mathrm{ml}$ filtered deionised water followed by $10 \mathrm{ml}$ scintillation fluid, and counted. The concentration of $\left[{ }^{3} \mathrm{H}\right]$ thymidine label, calculated from these counts, ranged from 10.1 to $14.5 \mathrm{nM}$ i slightly higher than the estimated value of $10 \mathrm{nM}$. [ $\left.{ }^{3} \mathrm{H}\right]$ thymidine incorporation by bacteria has been found to be almost constant for concentrations between 1 and $20 \mathrm{nM}$ in Southern Ocean waters (Bjornsen \& Kuparinen 1991) and it is likely that uptake will have been saturated in the present study.

Data analysis. Mean values presented for each experiment were based on either 3 values corresponding to 3 replicate $2.5 \mathrm{l}$ water bottle samples, or 30 values corresponding to 30 replicate cell volume measurements. All $95 \%$ confidence limits were calculated using the pooled standard deviation. In order to calculate the variance of HNAN and bacterial population volume, $v(P)$, the following formula was used:

$$
v(\mathrm{P})=v(\mathrm{~A}) E^{2}(\mathrm{C})+v(\mathrm{C}) E^{2}(\mathrm{~A})+v(\mathrm{~A}) v(\mathrm{C})
$$

where: $v(\mathrm{~A})=$ variance of the abundance data on the original scales; $v(C)=$ variance of the cell volume data on the original scales; $E(A)=$ mean abundance of 3 
replicates; and $E(I)=$ mean cell volume of 30 replicates. To test for significant changes in the abundance and cell volume of bacteria, FLB and HNAN, 1-way analyses of variance and $t$-tests were conducted. To determine the mean uptake rate of FLB HNAN ${ }^{-1} \mathrm{~h}^{-1}$, least squares regression was undertaken of the number of FLB cell ${ }^{-1}$ versus time (Sherr \& Sherr 1993). All analyses were performed using the MINITAB 10.1 statistical package (Minitab Inc., State College, PA, USA)

\section{RESULTS}

\section{Microbial abundance, biomass and production}

During the study period, the salinity and temperature of the experimental samples varied from 32.6 to $33.7 \%$ and from -1.4 to $-0.4^{\circ} \mathrm{C}$ respectively (Table 1 ). Mean chl a concentration increased from 6 and $5 \mu \mathrm{g} \mathrm{l}^{-1}$ during late December and early January respectively to a maximum of $19 \mu \mathrm{g} \mathrm{l^{-1 }}$ on 27 January, after which the concentration fell to $3 \mu \mathrm{g}^{-1}$ on 11 February (Table 1). The sampling period was therefore characterised by a distinct summer peak of algal biomass.

Bacterial abundance, biomass and production in experimental samples generally reflected chl a concentration with maximum values recorded in January. Mean bacterial abundance increased from $2 \times 10^{8} 1^{-1}$ during late December and early January to a maximum of $8 \times 10^{8} \mathrm{l}^{-1}$ on 20 January (Table 1 ). Abundance then declined to $4 \times 10^{8} \mathrm{l}^{-1}$ in February. Mean bacterial cell volume, determined by image analysis, did not vary significantly between experimental samples (ANOVA: $p=0.525$ ) ranging from 0.28 to $0.40 \mathrm{\mu m}^{3}$.
Changes in bacterial biomass therefore reflected changes in abundance and ranged from $13 \mu \mathrm{g} \mathrm{C} \mathrm{l}^{-1}$ on 30 December to $64 \mu \mathrm{g} \mathrm{C} \mathrm{l}^{-1}$ on 20 January (Table 1 ). Comparable biomass values calculated from cell volumes determined using an ocular micrometer ranged from $9 \mu \mathrm{g} \mathrm{C}^{-1}$ on 6 January to $40 \mu \mathrm{g} \mathrm{C} \mathrm{l}^{-1}$ on 20 January. Mean bacterial production, estimated from $\left.{ }^{3} \mathrm{H}\right]$ thymidine incorporation, ranged from $8 \mu \mathrm{g} \mathrm{Cl}^{-1} \mathrm{~d}^{-1}$

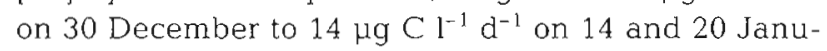
ary (Table 1).

The HNAN community in experimental samples comprised several different taxa which were grouped into the following 5 categories: small and large choanoflagellates, small and large non-collared HNAN, and colonial HNAN (Table 2). The linear dimensions of these taxa did not differ markedly and the size categories were distinguished primarily on the basis of shape and morphology. Mean total HNAN abundance in the experimental samples ranged from $1.6 \times 10^{6} \mathrm{I}^{-1}$ on 11 February to $4.2 \times 10^{6} \mathrm{I}^{-1}$ on 14 January (Table 1 ). As with bacteria, HNAN biomass broadly reflected abundance with minimum and maximum values of $8 \mu \mathrm{g} \mathrm{Cl}^{-1}$ and $16 \mu \mathrm{g} \mathrm{Cl}^{-1}$ recorded on 11 February and 14 January, respectively (Table 1). Choanoflagellates dominated the HNAN community at the beginning of the study period, comprising 56 and $65 \%$ of the total HNAN abundance and biomass, respectively, on 30 December with maximum values of $1.5 \times 10^{6} \mathrm{I}^{-1}$ and $8 \mu \mathrm{gC}^{-1}$ (Table 3, Fig. 2a, b). Abundance and biomass then declined by almost 2 orders of magnitude to $4 \times 10^{4} \mathrm{l}^{-1}$ and $0.2 \mu \mathrm{g} \mathrm{C} \mathrm{l^{-1 }}$ in February. Colonial HNAN exhibited a similar decline in numbers during the study period but were seldom common, achieving maximum abundance and biomass values of $6 \times 10^{5} \mathrm{I}^{-1}$

Table 1 Temperature, salinity, chl a concentration and the mean (with $95 \%$ confidence limits) abundance, biomass and production of bacteria and total HNAN recorded at $5 \mathrm{~m}$ depth in coastal waters of Prydz Bay, eastern Antarctica

\begin{tabular}{|c|c|c|c|c|c|c|c|c|}
\hline \multirow{2}{*}{$\begin{array}{l}\text { Expt } \\
\text { date }\end{array}$} & \multirow{2}{*}{$\begin{array}{c}\text { Temp. } \\
\left({ }^{\circ} \mathrm{C}\right)\end{array}$} & \multirow{2}{*}{$\begin{array}{c}\text { Salinity } \\
\text { (\%o) }\end{array}$} & \multirow{2}{*}{$\begin{array}{c}\text { Chl a } \\
\left(\mu \mathrm{gl}^{-1}\right)\end{array}$} & \multicolumn{3}{|c|}{-Bacteria-_ } & \multicolumn{2}{|c|}{ - Total HNAN } \\
\hline & & & & $\begin{array}{l}\text { Abundance } \\
\left(\times 10^{8} \mathrm{l}^{-1}\right)\end{array}$ & $\begin{array}{l}\text { Biomass } \\
\left(\mu \mathrm{g} \mathrm{Cl}^{-1}\right)\end{array}$ & 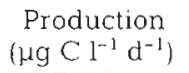 & $\begin{array}{c}\text { Abundance } \\
\left(\times 10^{6} \mathrm{l}^{-1}\right)\end{array}$ & $\begin{array}{l}\text { Biomass } \\
\left(\mu \mathrm{g} \mathrm{Cl}^{-1}\right)\end{array}$ \\
\hline 30 Dec 1993 & -0.5 & 33.6 & $\begin{array}{c}6.3 \\
(3.6-8.9)\end{array}$ & $\begin{array}{c}2.2 \\
(1.9-2.4)\end{array}$ & $\begin{array}{c}13.4 \\
(0.0-35.2)\end{array}$ & $\begin{array}{c}7.6 \\
\{5.4-9.8\}\end{array}$ & $\begin{array}{c}2.7 \\
(2.4-3.1)\end{array}$ & $\begin{array}{c}11.9 \\
(5.0-18.8)\end{array}$ \\
\hline 6 Jan 1994 & -1.1 & 33.7 & $\begin{array}{c}5.3 \\
(2.7-8.0\}\end{array}$ & $\begin{array}{c}2.1 \\
(1.8-2.4)\end{array}$ & $\begin{array}{c}18.4 \\
(0.0-39.7)\end{array}$ & $\begin{array}{c}12.7 \\
(9.6-15.8)\end{array}$ & $\begin{array}{c}2.9 \\
(2.6-3.2)\end{array}$ & $\begin{array}{c}14.8 \\
(7.9-21.7)\end{array}$ \\
\hline $14 \operatorname{Jan} 1994$ & -0.4 & 32.8 & $\begin{array}{c}13.4 \\
(10.7-16.0)\end{array}$ & $\begin{array}{c}5.8 \\
(5.5-6.1)\end{array}$ & $\begin{array}{c}39.8 \\
(0.0-97.6)\end{array}$ & $\begin{array}{c}14.3 \\
(11.9-16.7)\end{array}$ & $\begin{array}{c}4.2 \\
(3.9-4.5)\end{array}$ & $\begin{array}{c}16.2 \\
(5.7-26.7)\end{array}$ \\
\hline $20 \operatorname{Jan} 1994$ & -0.8 & 32.6 & $\begin{array}{c}13.2 \\
(10.6-15.9)\end{array}$ & $\begin{array}{c}8.3 \\
(8.0-8.6)\end{array}$ & $\begin{array}{c}63.5 \\
(0.0-145.5)\end{array}$ & $\begin{array}{c}14.2 \\
(11.5-16.9)\end{array}$ & $\begin{array}{c}2.8 \\
(2.5-3.1)\end{array}$ & $\begin{array}{c}12.6 \\
(2.8-22.4)\end{array}$ \\
\hline $27 \mathrm{Jan} 1994$ & -0.4 & 32.7 & $\begin{array}{c}18.5 \\
(15.9-21.2)\end{array}$ & $\begin{array}{c}5.1 \\
(4.8-5.4)\end{array}$ & $\begin{array}{c}41.1 \\
(0.0-91.7)\end{array}$ & $\begin{array}{c}13.0 \\
\{10.1-15.9\}\end{array}$ & $\begin{array}{c}3.1 \\
(2.8-3.4\}\end{array}$ & $\begin{array}{c}13.7 \\
(0.0-31.7)\end{array}$ \\
\hline 3 Feb 1994 & -0.9 & 32.7 & $\begin{array}{c}17.3 \\
(14.7-20.0)\end{array}$ & $\begin{array}{c}4.1 \\
(3.8-4.4)\end{array}$ & $\begin{array}{c}30.7 \\
(0.0-71.2)\end{array}$ & $\begin{array}{c}11.2 \\
(8.5-13.9)\end{array}$ & $\begin{array}{c}2.8 \\
(2.5-3.1)\end{array}$ & $\begin{array}{c}14.9 \\
(0.0-35.8\end{array}$ \\
\hline 11 Feb 1994 & -1.4 & 33.1 & $\begin{array}{c}3.2 \\
(0.5-5.8)\end{array}$ & $\begin{array}{c}3.9 \\
(3.6-4.2)\end{array}$ & $\begin{array}{c}30.4 \\
(0.0-69.1)\end{array}$ & $\begin{array}{c}8.9 \\
(6.2-11.7)\end{array}$ & $\begin{array}{c}1.6 \\
(1.3-1.9)\end{array}$ & $\begin{array}{c}7.5 \\
(0.0-17.5)\end{array}$ \\
\hline
\end{tabular}


Table 2. Mean cell length (with range) and volume (with $95 \%$ confidence limits) of HNAN taxa observed in experimental samples collected from $5 \mathrm{~m}$ depth betwen 30 Dec 1993 and 11 Feb 1994 in coastal waters of Prydz Bay, eastern Antarctica

\begin{tabular}{|lcc|}
\hline HNAN taxonomic group ${ }^{\text {d }}$ & $\begin{array}{c}\text { Mean cell } \\
\text { length }(\mu \mathrm{m})\end{array}$ & $\begin{array}{c}\text { Mean cell } \\
\text { volume }(\mu \mathrm{m})\end{array}$ \\
\hline Small choanoflagellate & 6.5 & 16.9 \\
Large choanoflagellate & $(4.1-10.2)$ & $(16.2-17.6)$ \\
& 7.8 & 34.9 \\
Small non-collared HNAN & $(4.3-15.0)$ & $(33.7-36.1)$ \\
& 2.5 & 3.3 \\
Large non-collared HNAN & $(1.8-4.2)$ & $(3.2-3.5)$ \\
& $(2.7-8.8)$ & 30.2 \\
Colonial HNAN & 4.8 & $27.3-33.2)$ \\
& $(3.3-6.7)$ & $(24.5-27.1)$ \\
aSmall and large taxa were distinguished primarily on the \\
basis of shape and morphology
\end{tabular}

and $4 \mu \mathrm{g} \mathrm{Cl}^{-1}$ on 6 January, equivalent to 21 and $29 \%$ of the total community (Table 3, Fig. 2a, b). In contrast to choanoflagellates and colonial HNAN, numbers of large non-collared HNAN increased during the study period and dominated the total HNAN community from mid January onwards. They comprised between 18 and $79 \%$ of the total HNAN abundance, and between 25 and $95 \%$ of the total HNAN biomass, with maximum values of $2 \times 10^{6} \mathrm{l}^{-1}$ and $14 \mu \mathrm{g} \mathrm{Cl}^{-1}$ recorded on 3 February (Table 3, Fig. 2a, b). Small non-collared HNAN contributed little to total HNAN biomass but were abundant throughout the study period reaching a maximum of $1.4 \times 10^{6} \mathrm{l}^{-1}$ on 14 January, equivalent to $34 \%$ of the total HNAN abundance (Table 3 , Fig. 2a, b)

HNAN bacterivory. Mean FLB concentration in experimental samples ranged from $9 \times 10^{7} 1^{-1}$ to $4 \times 10^{8} \mathrm{l}^{-1}$, equivalent to between 29 and $98 \%$ of the natural bacterial abundance or 22 to $49 \%$ of the total food particle concentration (FLB + bacteria). These final concentrations were greater than initially anticipated due in part to changes in natural bacterial abundance occurring at the experimental site between sampling events. Mean FLB cell volume in experimental samples ranged from 0.26 to $0.50 \mu^{3}$, tending to decrease towards the end of the study period, but not significantly (ANOVA: $p=$ 0.056). FLB cell volume was also similar to that of the natural bacteria with no significant difference observed between the two in all the experiments ( $t$-test, $p=0.079$ ).

Individuals of each of the HNAN taxa ingested FLB during the course of each experiment; the FLB within the choanoflagellates tending to accumulate at the posterior ends of the cell, as observed by Marchant \& Scott (1993) With the exception of small non-collared HNAN, which tended to ingest few FLB regardless of

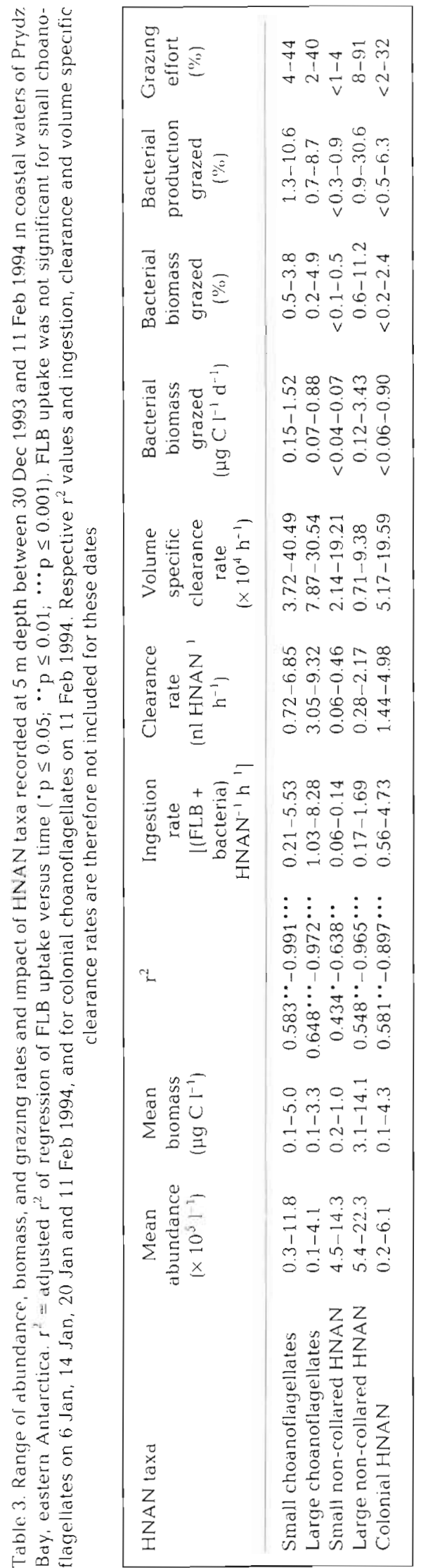



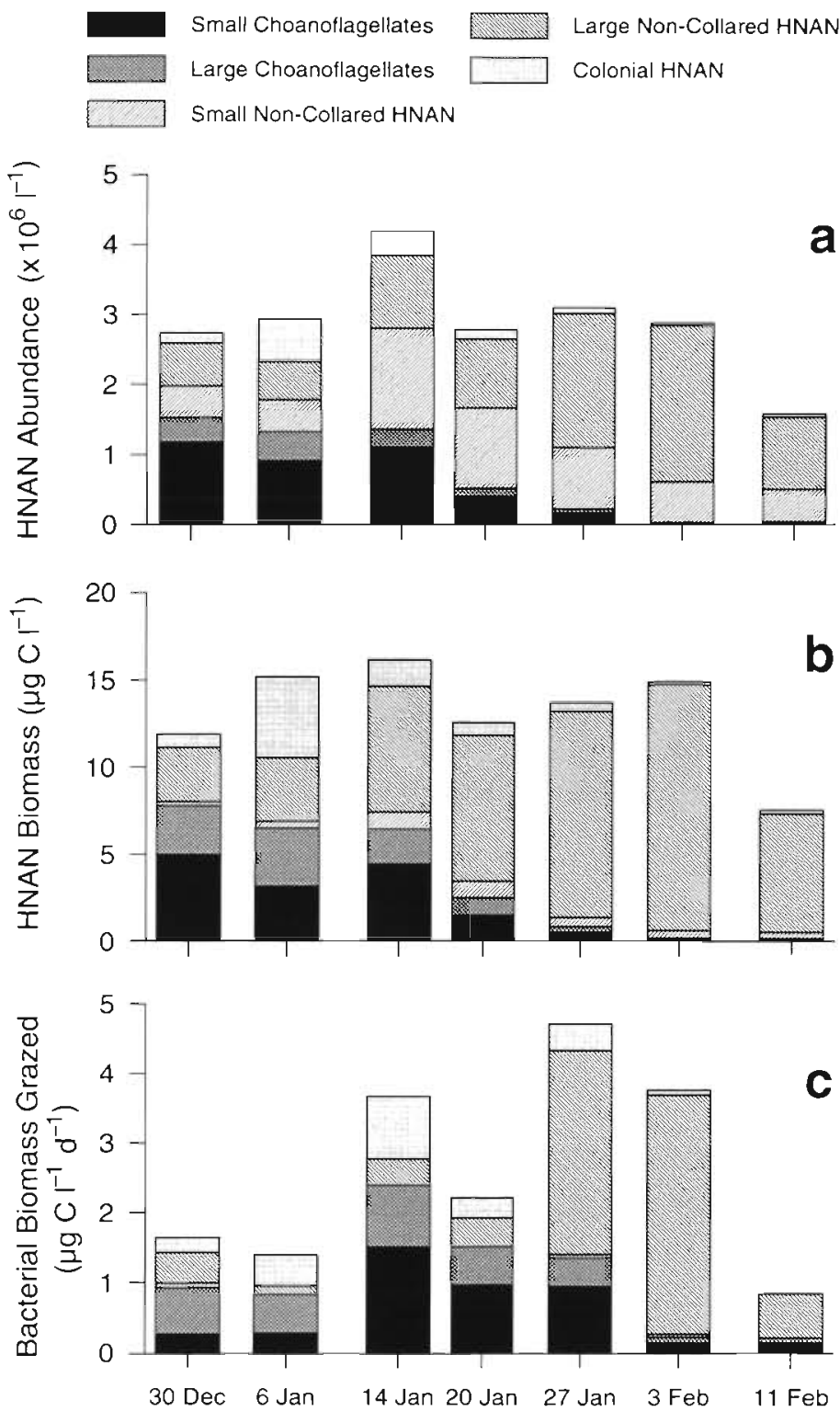

Experiment Date

Fig. 2. Mean (a) abundance, (b) biomass and (c) grazing impact of the 5 main categories of HNAN recorded during summer 1993/94 at $5 \mathrm{~m}$ depth in coastal waters of Prydz Bay, eastern Antarctica

incubation time, the number of HNAN cells observed with FLB, and the number of FLB observed within individual cells, increased with incubation time. Thus, after 80 min a maximum of $91 \%$ of large choanoflagellates had ingested FLB on 3 February, with a maximum of $13 \mathrm{FLB}$ observed cell ${ }^{-1}$ after $80 \mathrm{~min}$ on 27 January. In almost all cases, plots of the mean number of FLB cell ${ }^{-1}$ versus time revealed linear uptake of FLB between 10 and $80 \mathrm{~min}$, with a slower rate of uptake observed during the initial $10 \mathrm{~min}$. Regression analyses were therefore undertaken on data corresponding to the linear portion of each uptake curve. Cellular ingestion and clearance rates differed between taxa ranging from a minimum of 0.06 particles cell ${ }^{-1} \mathrm{~h}^{-1}$ and $0.06 \mathrm{nl} \mathrm{cell}^{-1} \mathrm{~h}^{-1}$, respectively, for small non-collared HNAN to a maximum of 8.28 particles cell ${ }^{-1} \mathrm{~h}^{-1}$ and $9.32 \mathrm{nl}$ cell ${ }^{-1} \mathrm{~h}^{-1}$ for large choanoflagellates (Table 3). Cellular ingestion and clearance rates recorded for each taxon also varied between experiments, and by approximately 1 order of magnitude for small choanoflagellates. However, no relationship was observed for any of the taxa between either ingestion rate and total particle concentration (regression: $\mathrm{r}^{2} \leq 0.257, \mathrm{p} \geq 0.140$ ), or clearance rate and total particle concentration (regression: $r^{2} \leq 0.013, p \geq 0.346$ ). Volume specific clearance rates varied between different taxa and between experiments from $0.7 \times 10^{4} \mathrm{~h}^{-1}$ for large non-collared HNAN to $4 \times 10^{5} \mathrm{~h}^{-1}$ for small choanoflagellates (Table 3 ).

During the study period the total HNAN population cleared between 3 and $12 \%$ of the water column, and thus equivalent percentages of bacterial abundance and biomass, daily (Table 4). The amount of bacterial carbon grazed ranged from $0.9 \mu \mathrm{g} \mathrm{Cl}^{-1} \mathrm{~d}^{-1}$ on 11 February to $4.7 \mu \mathrm{g} \mathrm{C} \mathrm{l}^{-1} \mathrm{~d}^{-1}$ on 27 January, equivalent to 10 and $36 \%$ of daily bacterial production respectively (Table 4, Fig. 2c). Choanoflagellates were responsible for much of the grazing impact at the beginning of the study period removing up to $7 \%$ of bacterial biomass and $17 \%$ of bacterial production per day and comprising up to $68 \%$ of the total HNAN grazing effort on 20 January (Table 3, Fig. 2c). Towards the end of the study large non-collared HNAN were the dominant grazers removing up to 11 and $31 \%$ ( 3 February) of bacterial biomass and production per day, respectively, equivalent to $91 \%$ of the total HNAN grazing effort. Colonial HNAN and small non-collared HNAN contributed $<32$ and $<4 \%$ of the total community grazing effort, respectively, throughout the study (Table 3, Fig. 2c).

\section{DISCUSSION}

\section{Microbial abundance, biomass and production}

Pelagic microbial abundance and biomass in Antarctic waters can vary considerably between locations and seasons. Highest values are generally recorded during the austral summer, associated with the receding marginal ice zone of oceanic waters and in neritic 
Table 4. Grazing impact of the total HNAN community recorded at $5 \mathrm{~m}$ depth in coastal wdters of Prydz Bay, eastern Antarctica

\begin{tabular}{|cccc|}
\hline Expt date & $\begin{array}{c}\text { Bacterial bio- } \\
\text { mass grazed } \\
\left(\mu \mathrm{g} \mathrm{C}^{-1} \mathrm{~d}^{-1}\right)\end{array}$ & $\begin{array}{c}\text { Bactenal bio- } \\
\text { mass grazed } \\
(\%)\end{array}$ & $\begin{array}{c}\text { Bacterial pro- } \\
\text { duction grazed } \\
(\%)\end{array}$ \\
\hline 30 Dec 1993 & 1.7 & 12.3 & 21.7 \\
6 Jan 1994 & 1.4 & 7.6 & 11.0 \\
14 Jan 1994 & 3.8 & 9.2 & 25.7 \\
20 Jan 1994 & 2.3 & 3.5 & 15.6 \\
27 Jan 1994 & 4.7 & 11.5 & 36.2 \\
3 Feb 1994 & 3.8 & 12.2 & 33.5 \\
11 Feb 1994 & 0.9 & 2.8 & 9.6 \\
\hline
\end{tabular}

waters (Priddle et al. 1992). The abundance and biomass values reported in this study, undertaken in a coastal locality during summer months, are therefore expected to be relatively high when compared to values recorded during winter months or from many oceanic Antarctic environments.

Chl a concentrations recorded in experimental samples increased during the study period to a mid summer peak of $19 \mu \mathrm{g} \mathrm{l}^{-1}$, then declined rapidly. This pattern of mid summer chl a maxima is characteristic of the study site (Perrin et al. 1987) and other Antarctic coastal pelagic environments at King George Island (Lipski 1987), Signy Island (Clarke et al. 1988, Clarke \& Leakey 1996) and McMurdo Sound (Rivkin 1991). Concurrent observations at the sample site revealed the algal community to be dominated by a small centric diatom Actinocyclus sp., Phaeocystis sp. and cryptomonads with between 4 and $74 \%$ of chl a within the nanophytoplankton (2 to $20 \mu \mathrm{m}$ ) size fraction ( $\mathrm{J}$. Grey \& R. J. G. Leakey unpubl.).
Mean bacterial abundance during the study period ranged from 2 to $8 \times 10^{8} \mathrm{l}^{-1}$ Previous studies undertaken offshore from Davis station have reported similar bacterial abundance values for the December to February period, as have other Antarctic coastal studies undertaken during summer in McMurdo Sound and offshore from Signy Island, King George Island and Adélie Land (Table 5). In contrast to bacterial abun-

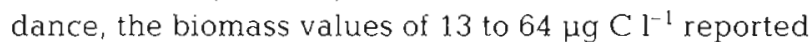
in this study are amongst the highest recorded for Antarctic coastal waters (Table 5); however, this can be attributed to the use of different methods to size bacterial cells. In the present study, cell sizes were measured by both image analysis and ocular micrometer. The former method is likely to be more accurate as it accounts for variations in cell shape, calculating cell volume from cell area and perimeter rather than single length and breadth measurements. In all experiments, average cell volume estimated by image analysis was greater than when estimated by ocular micrometer resulting in higher biomass values: 13 to 64 versus 9 to $40 \mu \mathrm{g} \mathrm{C} \mathrm{l}^{-1}$, respectively. The latter values are generally similar to values reported from Antarctic coastal studies where bacterial cell volume has been estimated by ocular micrometer (Table 5). The use of different factors to convert bacterial cell volume to carbon biomass also contributes towards differences between biomass estimates. Other coastal Antarctic studies have used carbon conversion factors of between 0.121 and $0.4 \mathrm{pg} \mathrm{C} \mu \mathrm{m}^{-3}$ (Table 5). The value of $0.22 \mathrm{pg} \mathrm{C} \mathrm{mm}^{-3}$ (Bratbak \& Dundas 1984) used in the present study lies within this range and has been used in previous studies undertaken offshore from Signy Island and King George Island (Table 5). However, a

Table 5. Bacterial abundance and biomass values recorded from Antarctic coastal waters

\begin{tabular}{|c|c|c|c|c|c|c|}
\hline Location & Season & $\begin{array}{l}\text { Abundance } \\
\left(\times 10^{8} 1^{-1}\right)\end{array}$ & $\begin{array}{l}\text { Biomass } \\
\left(\mu g \mathrm{CI}^{-1}\right)\end{array}$ & $\begin{array}{l}\text { Conversion } \\
\text { factor }\left(p g C \mu \mathrm{m}^{3}\right)\end{array}$ & $\begin{array}{l}\text { Sizing } \\
\text { method }^{a}\end{array}$ & Reference $^{b}$ \\
\hline McMurdo & Dec-Jan & $0.6-10$ & $0.5-8$ & 0.121 & SEM & 1 \\
\hline \multirow[t]{2}{*}{ Sound } & Dec-Jan & $0.6-9.6$ & - & - & - & 2 \\
\hline & Sep-Jan & $<0.4->2.5$ & - & - & - & 3 \\
\hline $\begin{array}{l}\text { Géologie Archepelago, } \\
\text { Adélie Land }\end{array}$ & Annual & $0.5->1.0$ & $1->30$ & 0.4 & OM & 4 \\
\hline $\begin{array}{l}\text { Admiralty Bay, } \\
\text { Kung George Island }\end{array}$ & Dec-Jan & $2.6-7$ & $8-37$ & 0.22 & - & 5 \\
\hline Borge Bay, Signy Island & Annual & $0.3-3$ & $<1-8$ & 0.22 & $\mathrm{OM}$ & 6 \\
\hline \multirow[t]{3}{*}{ Prydz Bay } & May $=\operatorname{Jan}$ & $<0.1-10$ & - & - & - & 7 \\
\hline & Nov-Feb & $<1-6$ & - & - & - & 8 \\
\hline & Dec-Feb & $2-8$ & $13-64$ & 0.22 & $\mathrm{IA}$ & 9 \\
\hline
\end{tabular}

"Methods used to size bacteria: $\mathrm{SEM}=$ scanning electron microscopy; OM = ocular micrometer; $\mathrm{IA}=$ image analy:sis

bources: 1 = Fuhrman \& Azam (1980); 2 = Elodson et al. (1981); $3=$ Rivkin (1991); $4=$ Delille (1993); $5=$ Vosjan \& OlańczukNeyman $(1991) ; 6=$ Leakey et al. $(1994) ; 7=$ Cibson el al. $(1990) ; 8=$ Davidson \& Marchant $(1992) ; 9=$ this study 
recent study using single cell elemental analysis suggests that lower carbon conversion factors may be more appropriate for natural aquatic bacteria (Fagerbakke et al. 1996); the bacterial biomass values presented in this and other Antarctic coastal studies may therefore be overestimates.

Several studies have measured bacterial production in Antarctic waters by $\left[{ }^{3} \mathrm{H}\right]$ thymidine incorporation (e.g. Fuhrman \& Azam 1980, Sullivan et al. 1990, Delille 1993), reporting rates ranging from $<0.1$ to $17 \mu \mathrm{g} \mathrm{Cl}^{-1}$ $\mathrm{d}^{-1}$ (reviewed by Ducklow \& Carlson 1992). Mean bacterial production in the present study varied from 8 to $14 \mu \mathrm{g} \mathrm{Cl}^{-1} \mathrm{~d}^{-1}$ and was therefore within the upper range of values reported from Antarctic waters. The calculation of bacterial production from $\left[{ }^{3} \mathrm{H}\right]$ thymidine incorporation requires the use of 2 conversion factors: one to convert thymidine incorporation to bacterial growth (the thymidine conversion factor) and another to convert bacterial growth to carbon biomass (the carbon conversion factor) (Bell 1993). Thymidine conversion factors used in other Antarctic studies range from 0.2 to $20 \times 10^{18}$ cells mol $^{-1}$ (e.g. Fuhrman \& Azam 1980, Rivkin 1991; reviewed by Ducklow \& Carlson 1992). The experimentally determined value of $1.91 \times 10^{18}$ cells $\mathrm{mol}^{-1}$ used in the present study therefore lies within this range and is similar to mean experimentally determined values of $1.1 \times 10^{18}$ and $2.2 \times 10^{18}$ cells mol $^{-1}$ reported from Antarctic waters by Bjornsen \& Kuparinen (1991) and Rivkin et al. (1989), respectively. The use of carbon conversion factors has been discussed above, and it follows that the high bacterial biomass values recorded in the present study will in turn have contributed to the relatively high estimates of bacterial production.

The few studies to have accurately quantified heterotrophic flagellates in Antarctic waters have generally been undertaken in oceanic environments revealing abundances as high as $10^{5}$ to $10^{6} \mathrm{l}^{-1}$ and biomass values up to $60 \mu \mathrm{g} \mathrm{C} \mathrm{l}^{-1}$ (reviewed by Garrison \& Gowing 1993). The total HNAN abundance and biomass values recorded in the present study are relatively high, with maxima of $4.2 \times 10^{6} \mathrm{l}^{-1}$ and $16.2 \mu \mathrm{g} \mathrm{C}$ $\mathrm{I}^{-1}$; this probably reflects the productive nature of Antarctic coastal waters during the austral summer. In contrast to previous Antarctic studies, the biomass values reported in the present study were derived using image analysis and a carbon conversion factor of 0.22

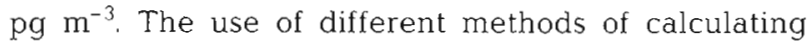
HNAN biomass will, therefore, again have contributed to the differences between estimates from different Antarctic studies. Several studies have reported shrinkage of HNAN upon fixation with glutaraldehyde (Børsheim \& Bratbak 1987, Bloem et al. 1988, Choi \& Stoecker 1989, Hondeveld et al. 1992) and it is likely that the fixation protocol used in the present study will have altered HNAN cell volume. However, use of the above carbon conversion factor, calculated for a bacterivorous Monas sp. fixed in $0.5 \%$ glutaraldehyde and stained with DAPI (Borsheim \& Bratbak 1987), will have helped compensate for such cell volume changes.

The HNAN community in experimental samples comprised a variety of taxa including choanoflagellates and non-collared forms. Choanoflagellates are common in Antarctic waters and the abundance and community composition of choanoflagellates in waters offshore from Davis station has been previously studied in detail (Marchant 1985, Marchant \& Perrin 1990, Davidson \& Marchant 1992). Three species, Bicosta spinifera, Crinolina aperta and Parvicorbicula socialis, dominate the community during the austral summer with maximum abundances recorded in January and February (Marchant \& Perrin 1990). It was not possible to identify choanoflagellates precisely from the slide preparations used in this study; however, the small choanoflagellates closely resembled Bicosta sp. in size and shape. Choanoflagellates achieved a maximum abundance in experimental samples of $1.5 \times 10^{6} \mathrm{I}^{-1}$, comparable to a peak of $1.2 \times 10^{6} \mathrm{l}^{-1}$ previously observed offshore from Davis station in early January (Davidson \& Marchant 1992). It is clear from the present study that choanoflagellates dominate the total HNAN community in late December and early January while other unidentified non-collared HNAN were quantitatively more important later in the summer. The abundance of colonial HNAN tended to decline during the study period in a similar manner to that of choanoflagellates. It was not possible to identify the colonial HNAN; however, it is likely that the colonial choanoflagellate Parvicorbicula socialis was included in this group.

\section{Grazing methodology}

Several methods have been used to measure protistan bacterivory in planktonic environments (reviewed by McManus \& Fuhrman 1988b, also see Berninger et al. 1991a and Landry 1994). The use of fluorescently labelled particles as tracers of bacterial ingestion offers several advantages over other methods including the use of short incubation times, minimal manipulation of samples, and the derivation of taxon specific grazing rates (Sherr \& Sherr 1993). However, the technique has potential limitations which should be considered when assessing estimates of HNAN bacterivory. These include: rapid or random digestion of FLB by HNAN during linear uptake of FLB; selective grazing by HNAN on labelled or non-labelled particles; alteration of HNAN grazing rate by increasing the concentration of food particles; and egestion of HNAN food vacuoles 
upon preservation (Sherr et al. 1989, McManus \& Okubo 1991). In addition, and in common with all methods of measuring protistan grazing by incubating natural samples, containment effects may influence grazing rates (Venrick et al. 1977, Peters \& Gross 1994).

In grazing experiments using FLB as tracers of ingestion, incubation times are kept to a minimum in order to ensure that the uptake of FLB versus time is linear during the course of each experiment. Linear increase in FLB uptake with time discontinues when the first FLB ingested have been completely digested or egested; experimental incubation times should therefore be less than the time taken to digest or egest FLB (Sherr \& Sherr 1993). Rapid or random digestion of FLB by HNAN would clearly lead to an underestimation of ingestion rate; however, it has been shown that an initial processing period exists during which digestion proceeds to a point when FLB are no longer identifiable (Sherr et al. 1988). This processing period has been found to increase with decreasing temperature from $34 \mathrm{~min}$ at $20^{\circ} \mathrm{C}$ to $80 \mathrm{~min}$ at $12^{\circ} \mathrm{C}$ for a mixed assemblage of marine HNAN (Sherr et al. 1988), suggesting that an incubation period of $80 \mathrm{~min}$ is appropriate for experiments undertaken in cold Antarctic waters. This was confirmed by the linear uptake rates recorded between 10 and $80 \mathrm{~min}$ in the present study. Uptake was slower during the initial $10 \mathrm{~min}$ of each experiment, perhaps due to the effects of gently mixing experimental samples to disperse FLB at the beginning of each incubation.

In the present study, FLB were prepared using natural bacteria collected from the experimental site 3 to $4 \mathrm{~d}$ prior to each experiment. This approach requires more effort than the alternative of staining cultured bacteria, but simulates more accurately the characteristics of the natural bacterial population. The cell volumes of FLB were similar to those of natural bacteria, suggesting that staining did not alter overall cell size. However, there is some evidence that flagellates may select motile living bacterial cells in preference to heat-killed FLB with subsequent grazing rates underestimated by $50 \%$ or more (Landry et al. 1991, Monger \& Landry 1992, González et al. 1993, Fuhrman \& Nobel 1995).

Ideally FLB should be added to experimental samples in sufficient concentration to allow measurable uptake during short incubations, but without greatly increasing the concentration of food particles available to the bacterivores. An optimal concentration of about $30 \%$ of total bacterioplankton has therefore been recommended (Sherr \& Sherr 1993). In the present study, logistical constraints precluded the accurate quantification of bacterioplankton concentration in experimental samples prior to adding FLB. Conse- quently, final FLB concentrations varied between experiments and were equivalent to between 29 and $98 \%$ of the total bacterioplankton concentration, corresponding to between 22 and $49 \%$ of the total food particle concentration (FLB + bacteria). When HNAN ingestion is not saturated cellular ingestion rates increase with increasing food concentration. In such circumstances addition of surrogate food particles may provide ingestion rates that are greater than ingestion rates for natural particles alone (McManus \& Okubo 1991). Half-saturation constant values of between 1.3 and $38 \times 10^{9}$ bacteria $\mathrm{l}^{-1}$ have been recorded for a range of laboratory cultured HNAN grown at $20^{\circ} \mathrm{C}$ (Fenchel 1982) and these values are greater than the maximum food particle concentration of $1.1 \times 10^{9} 1^{-1}$ recorded in the present study. This suggests that HNAN ingestion may not have been saturated in the experimental samples; although it should be noted that ingestion rates, and thus half-saturation constants, are likely to be lower at lower temperatures (Caron et al. 1986, Sherr et al. 1988, Tobiesen 1990, Choi \& Peters 1992). Cellular ingestion rates varied considerably between experiments; however, no significant relationship was detected between ingestion rate and total particle concentration. This prevented an assessment of the degree to which the recorded particle ingestion rates may have overestimated natural bacterial ingestion rates (McManus \& Okubo 1991). In contrast to ingestion rate, HNAN cellular clearance rate may decrease with increasing food particle concentration (Fenchel 1982). The addition of different concentrations of FLB may therefore have led to differential underestimation of cellular clearance rates in the present study, which will in turn have led to the underestimation of population grazing impact. Although clearance rates varied between experiments, no relationship was detected between clearance and total particle concentration, again preventing an assessment of the degree to which rates may have been underestimated.

Egestion of HNAN food vacuoles upon fixation with glutaraldehyde has been reported (Sieracki et al. 1987 , McManus \& Fuhrman 1988a) and may lead to an underestimation of FLB ingestion. However, ice-cold glutaraldehyde has been successfully used in HNAN grazing experiments using FLB as tracers of ingestion (Bloem et al. 1989, Sherr et al. 1989) and there was no evidence of food vacuole egestion in the present study. In this context, it is significant that the choanoflagellate clearance rates reported in the present study, which varied from 0.2 to $8.28 \mathrm{nl} \mathrm{cell}^{-1} \mathrm{~h}^{-1}$, were in most cases higher than the maximum clearance rates of $0.7 \mathrm{nl}$ cell ${ }^{-1} \mathrm{~h}^{-1}$ measured at $0^{\circ} \mathrm{C}$ on live individuals of the choanoflagellate Diaphanoeca grandis isolated from sea ice (Marchant 1990). 


\section{HNAN bacterivory}

The HNAN clearance and ingestion rates recorded in the present study ranged from 0.06 to $9.32 \mathrm{nl} \mathrm{cell}^{-1}$ $\mathrm{h}^{-1}$ and 0.06 to 8.28 particles cell $\mathrm{l}^{-1} \mathrm{~h}^{-1}$ respectively. There is little information available on the grazing rates of HNAN in Antarctic waters but a maximum clearance rate of $3 \mathrm{nl}$ celli $\mathrm{i}^{-1} \mathrm{~h}^{-1}$ has been recorded for the choanoflagellate Acanthocorbis unguiculata in waters offshore from Davis station (Marchant \& Scott 1993). An ingestion rate of 30 bacteria cell ${ }^{-1} \mathrm{~h}^{-1}$ has also been recorded at $-1.8^{\circ} \mathrm{C}$ for cultures of the bacterivorous HNAN Paraphysomonas imperforata isolated from Arctic waters (Choi \& Peters 1992). The maximum cellular clearance and ingestion rates recorded in the present study fall within the range of values commonly observed in warmer water environments, although maximum rates from temperate and tropical waters are generally higher (Berninger et al. 1991a, Carlough \& Meyer 1991, Vaqué et al. 1994). This is to be expected as HNAN ingestion rate is positively related to temperature both in culture (Caron et al. 1986, Sherr et al. 1988, Tobiesen 1990, Choi \& Peters 1992) and in field populations (Peters 1994. Vaqué et al. 1994), and choanoflagellate grazing rates are considered to be lower in cold waters (Marchant \& Scott 1993).

During the study period, HNAN removed an estimated 0.9 to $4.7 \mu \mathrm{g}$ of bacterial carbon $\mathrm{I}^{-1} \mathrm{~d}^{-1}$, equivalent to between 3 and $12 \%$ of bacterial biomass and 10 and $36 \%$ of bacterial production. HNAN carbonbased gross growth efficiency can vary with temperature and prey condition, with higher values recorded at lower temperatures (Caron et al. 1986, Choi \& Peters 1992, González et al. 1993). Assuming a gross growth efficiency of approximately $30 \%$ (Caron \& Goldman 1990), the biomass of bacteria consumed by the total HNAN community in the present study would support doubling times of 8 to $40 \mathrm{~d}$. These are likely to be minimum estimates due to consumption by HNAN of other sources of food such as high molecular weight dissolved organic matter (Sherr 1988, Marchant \& Scott 1993), viruses (González \& Suttle 1993), cyanobacteria (Caron et al. 1991, Kuosa 1991) and other protists (Sanders 1991).

There are currently no other studies from Antarctic waters which have attempted comprehensively to estimate total HNAN community bacterivory concurrently with estimates of bacterial biomass and production. It is therefore not possible to compare HNAN community grazing impact with values from other Antarctic localities. Marchant \& Scott (1993) have, however, estimated that choanoflagellates would clear $7 \%$ of surface waters per day offshore from Davis station during summer. In this study, choanoflagellates also cleared up to $7 \%$ of daily bacterial biomass. When compared to some non-polar marine environments, where flagellate grazing may account for the entire daily bacterial production (Berninger et al. 1991a, Capriulo et al. 1991), the grazing impact of HNAN reported in this study is relatively low.

In a stable community where bacterial abundance is not changing, bacterial loss processes should balance production. Where HNAN bacterivory is the primary source of bacterial mortality, consumption of bacteria by HNAN should approximately balance daily bacterial production. During the present study bacterial abundance remained relatively stable yet the HNAN community removed less than half of the bacterioplankton production. The discrepancy between the magnitude of bacterial production and HNAN bacterivory could be due to either uncoupling of production and grazing during the study period, methodological problems, or other sources of bacterial mortality.

Uncoupling of bacterial production and HNAN grazing is to be expected in some experimental samples due to predator prey oscillations which may occur diurnally, or over a period of days to weeks (Sherr et al. 1989, Sanders et al. 1992). The consistently low grazing impact of HNAN on bacterial production observed in the present study over a 7 wk period suggests that uncoupling over a time period of days to weeks is unlikely to be responsible for the low grazing impact of HNAN. All 7 experiments were undertaken during the early afternoon and would have been equally susceptible to differential diurnal cycles of grazing and production. Diurnal cycles of bacterial production and flagellate bacterivory have been observed in temperate and tropical waters (Fuhrman et al. 1985, Weisse 1989, Wikner et al. 1990), with both processes closely coupled in some cases (Weisse 1989, Wikner et al. 1990). However, such diurnal variation is less likely during the periods of almost continuous daylight experienced at high latitude sites during mid summer.

Methodological problems associated with the estimation of bacterial production and HNAN bacterivory have been discussed above. In addition, HNAN may preferentially select larger, actively growing bacteria within natural bacterial assemblages, thus cropping bacterial production more effectively (Andersson et al. 1986, Gonzalez et al. 1990, Sherr et al. 1992). Such selectivity would lead to an underestimate of the grazing impact of the HNAN population on both bacterial biomass and production. HNAN may also selectively graze on bacteria associated with aggregates (Caron 1987, Sibbald \& Albright 1988); such ingestion would not be detected using FLB leading to an underestimation of grazing impact. By contrast, attachment to suspended particles may also give bacteria a refuge from grazing so that the amount of production available to 
grazers will have been overestimated (Jürgens \& Güde 1994). The magnitude of bacterial production associated with particles was not assessed in the present study, but may have been significant (Pedrós-Alió \& Brock 1983).

On balance it would seem likely that HNAN bacterivory will have been underestimated in the present study, particularly due to the methodological problems associated with possible preferential selection of live bacteria. For HNAN bacterivory to balance bacterial production, grazing rates would have to be underestimated by a factor of between 2.8 and 10 . Given that preferential selection of live bacteria could underestimate grazing rates by more than $50 \%$, it would seem likely that HNAN bacterivory may, on occasion, have balanced bacterial production. However, alternative sources of bacterial mortality, which include spontaneous death and lysis of bacteria, lysis due to infection by lytic bacteria, lysis due to bacteriophage, starvation. sedimentation and grazing by other organisms, are likely to have been of significance during most experiments (McManus \& Fuhrman 1988b, Pace 1988, Sherr et al. 1989).

Little information is available on the possibility of spontaneous lysis or on infection by lytic bacteria, although the latter have been isolated from natural waters (Shilo 1984, McManus \& Fuhrman 1988b). While starvation is likely to influence the seasonal abundance of bacterioplankton, it is probably a minor component of daily bacterial mortality (Pace 1988). The magnitude of bacterial loss from Antarctic coastal waters due to sedimentation is also not known but could be significant if a substantial component of the bacterial population is associated with particles or flocs. Recently it has been demonstrated that bacteriophages can be numerous in marine waters (Bergh et al. 1989), including the Southern Ocean (Smith et al. 1992), and up to $36 \%$ of bacterioplankton mortality has been attributed to viral lysis in Arctic waters (Steward et al. 1996). Viral-induced lysis may therefore have been a significant cause of bacterial mortality in the present study.

Grazing by other protists and metazodns may also be responsible for significant bacterial mortality. Many metazoan zooplankton consume marine bacteria but they are generally inefficient at capturing small planktonic bacteria and grazing impacts on bacterioplankton populations appear to be low (King et al. 1980, Jørgensen 1984, Turner et al. 1988). The magnitude of bacterial mortality due to metazoan grazers is likely to be greater in coastal. waters where much production may be attributable to particle-attached bacteria and thus grazed more efficiently (Lawrence et al. 1993). Benthic suspension feeders can be active during much of the year in Antarctic coastal waters (Barnes \&
Clarke 1995 ) but their impact upon bacterial populations is not known. Other protists, and in particular heterotrophic dinoflagellates (Lessard 1991, Never \& Cowles 1995), small ciliates (Sherr \& Sherr 1994) and pigmented flagellates (Porter 1988, Sanders 1991) may be important bacterivores in pelagic waters. The grazing impact of these groups on Antarctic bacterioplankton is not known; however, planktonic ciliates and heterotrophic dinoflagellates were common in surface waters during the study period (Archer et al. in press, Grey \& Leakey unpubl.) and may have been responsible for significant bacterial mortality. Pigmented nanoflagellates did not appear from incidental observations to have ingested FLB in present study.

There has recently been much debate on the degree to which bacterioplankton populations are controlled and limited by bottom-up (i.e. resources) or top-down (i.e. predation) factors in both marine and freshwater environments (Billen et al. 1990, Berninger et al. 1991b, Ducklow 1992, Sanders et al. 1992, Gasol \& Vaques 1993, Pace \& Cole 1994). It is likely that both processes operate to varying degrees according to the heterogeneity of the community (Hunter \& Price 1992); however, there is some evidence that bottom-up control may be more important in regulating bacterial abundances in oligotrophic environments, while top-down control may be more important in eutrophic environments (Sanders et al. 1992). It is not clear to what extent either mechanism limited bacterial growth in the present study, but HNAN bacterivory appears insufficient on its own to exert topdown control. HNAN may themselves be subject to predation by ciliates (Verity 1991), dinoflagellates (Kuparinen \& Bjørnsen 1992) and metazoan zooplankton (Stoecker \& Capuzzo 1990), and such predation may have indirectly reduced the extent of HNAN bacterivory in the present study. The effects of such 'trophic cascades' (Sanders et al. 1992) are complex, influencing the regeneration of nutrients available to bacteria as well as grazing mortality. HNAN bacterivory is therefore likely to be one of several factors influencing the magnitude of bacterial production in the cold and highily seasonal waters offshore from Davis station.

Acknowledgements. We acknowledge the generous support of the Australian Antarctic Division and in particular Harvey Marchant, Andrew Davidson and all the friends and colleagues who made up the A.N.A.R.E at Davis station during 1993/94. We are also grateful to the 3 anonymous reviewers for their helpful comments on the manuscript. This study forms part of the pelagic ecosystems research programme of the British Antarctic Survey, and was supported in part by an NERC Antarctic Special Topic research grant (GST/02/0656) and an NERC research studentship (GT 4/32/175/A). 


\section{LITERATURE CITED}

Andersson A, Larsson U, Hagström A (1986) Size-selective grazing by a microflagellate on pelagic bacteria. Mar Ecol Prog Ser 33:51-57

Archer SD, Leakey RJG, Burkill PH, Sleigh MA (1996) Microbial dynamics in codstal waters of East Antarctica: herbivory by heterotrophic dinoflagellates. Mar Ecol Prog Ser 139:239-255

Azam F, Fenchel T, Fleld JG, Gray JS, Meyer-Reil LA, Thingstad F (1983) The ecological role of water-column microbes in the sea. Mar Ecol Prog Ser 10:257-263

Barnes DKA, Clarke A (1995) Seasonality of feeding activity in Antarctic suspension feeders. Polar Biol 15:335-340

Bell RT (1993) Estimating production of heterotrophic bacterioplankton via incorporation of tritiated thymidine. In: Kemp PF, Sherr BF, Sherr EB, Cole JJ (eds) Handbook of methods in aquatic microbial ecology. Lewis, Boca Raton, p 495-503

Bergh $\varnothing$, Børsheim KY, Bratbak G, Heldal M (1989) High abundance of viruses found in aquatic environments. Nature 340:467-468

Berninger UG, Caron DA, Sanders RW, Finlay BJ (1991a) Heterotrophic flagellates of planktonic communities, their characteristics and methods of study. In: Patterson DJ, Larsen J (eds) The biology of free-living heterotrophic flagellates. Clarendon Press, Oxford, p 39-56

Berninger UG, Finlay BJ, Kuuppo-Leinikki P (1991b) Protozoan control of bacterial abundances in freshwater. Limnol Oceanogr 36:139-147

Billen G, Servais P, Becquevort S (1990) Dynamics of bacterioplankton in oligotrophic and eutrophic aquatic environments: bottom-up or top-down control. Hydrobiologia 207: $37-42$

Bjornsen PK, Kuparinen J (1991) Determınatıon of bacterioplankton biomass, net production and growth efficiency in the Southern Ocean. Mar Ecol Prog Ser 71:185-194

Bloem J. Ellenbroek FM, Bar-Gilissen MB. Cappenberg TE (1989) Protozoan grazing and bactenal production in stratified lake Vechten estimated with fluorescently labeled bacteria and by thymidine incorporation. Appl Environ Microbiol 55:1787-1795

Bloem J, Starink M, Bär-Gilissen MB, Cappenberg TE (1988) Protozoan grazing, bacterial activity, and mineraluzation in two-stage continuous cultures. Appl Environ Microbiol 54 3113-3121

Børsheim KY, Bratbak G (1987) Cell volume to cell carbon conversion factors for a bacterivorous Monas sp. enriched from seawater Mar Ecol Prog Ser 36:171-175

Bratbak G, Dundas I (1984) Bacterial dry matter content and biomass estimations. Appl Environ Microbiol 48:755-757

Buck KR, Chavez FP, Thomsen HA (1991) Choanoflagellates of the central California waters: abundance and distribution. Ophelia 33:179-186

Capriulo GM, Sherr EB, Sherr BF (1991) Trophxc behaviour and related community feeding activities of heterotrophic marine protists. In Reid PC, Turley CM, Burkill PH (eds) Protozoa and their role in marine processes. SpringerVerlag, Berlin, p 219-265

Carlough LA, Meyer JL (1991) Bacterivory by sestonic protists in a southeastern blackwater river Limnol Oceanogr 36 : 873-883

Caron DA (1987) Grazing of attached bacteria by heterotrophic microflagellates. Microb Ecol 13:203-218

Caron DA, Goldman JC (1990) Protozoan nutrient regeneratıon. In: Capriulo GM (ed) Ecology of marine protozoa Oxford University Press, Oxford, p 283-306
Caron DA, Goldman JC, Dennett MR (1986) Effect of temperature on growth, respiration, and nutrient regeneration by an omnivorous microflagellate. Appl Environ Microbiol 52:1340-1347

Caron DA, Lim EL, Miceli G, Waterbury JB, Valois FW (1991) Grazing and utilization of chroococcoid cyanobacteria and heterotrophic bacteria by protozoa in laboratory cultures and a coastal plankton community. Mar Ecol Prog Ser 76 $205-217$

Choi JW, Peters F (1992) Effects of temperature on two psychrophilic ecotypes of a heterotrophic nanoflagellate, Paraphysomonas imperforata. Appl Environ Microbicl 58: $593-599$

Chol JW, Stoecker DK (1989) Effects of fixation on cell volume of marine planktonic protozoa. Appl Environ Microbiol $55: 1761-1765$

Clarke A, Holmes LJ, White MG (1988) The annual cycle of temperature, chlorophyll and major nutrients at Signy Island, South Orkney Islands, 1969-1982. Br Antarct Surv Bull 80:65-86

Clarke A, Leakey RJG (1996) The seasonal cycle of phytoplankton, macronutrients and the microbial community in a nearshore Antarctic marine ecosystem. Limnol Oceanogr 41:1281-1294

Cole JJ, Findlay S, Pace ML (1988) Bacterial production in fresh and saltwater ecosystems: a cross-system overview. Mar Ecol Prog Ser 43:1-10

Davidson AT, Marchant HJ (1992) Protist abundance and carbon concentration during a Phaeocystis-dominated bloom at an Antarctic coastal site. Polar Biol 12:387-395

Delille D (1993) Seasonal changes in the abundance and composition of marne heterotrophic bacterial communities in an Antarctic coastal area. Polar Biol 13:463-470

Ducklow HW (1992) Factors regulating bottom-up control of bacterial biomass in open ocean plankton communities. Arch Hydrobiol Beih Ergeb Limnol 37:207-217

Ducklow HW, Carlson Crl (1992) Oceanic bacterial productıon. In: Marshall KC: (ed) Advances in microbial ecology. Plenum Press, New York, p 113-181

Fagerbakke KM, Hedal M, Norland S (1996) Content of carbon, nitrogen, oxygen, sulfur and phosphorus in native aquatic and cultured bacteria. Aquat Microb Ecol 10:15-27

Fenchel T (1982) Ecology of heterotrophic microflagellates. II. Bioenergetics and growth. Mar Ecol Prog Ser 8:225-231

Fenchel T (1988) Marine plankton food chains. Annu Rev Ecol Syst 19:19-38

Fry JC, Davies AR (1985) An assessment of methods for measuring volumes of planktonic bacteria, with particular reference to television image analysis. J Appl Bacteriol 58:105-112

Fuhrman JA, Azam F (1980) Bacterioplankton secondary production estimates for coastal waters of British Columbia, Antarctica, and California. Appl Environ Microbiol 36: 1085-1095

Fuhrman JA, Eppley RW, Hagström A, Azam F (1985) Diel variations in bacterioplankton, phytoplankton, and related parameters in the Southern California Bight. Mar Ecol Prog Ser 27:9-20

Fuhrman JA, Noble RT (1995) Viruses and protists cause similar mortality in coastal seawater Limnol Oceanogr 40:1236-1242

Garrison DL, Gowing MM (1993) Protozooplankton. In: Friedmann El (ed) Antarctic microbiology. Wiley-Liss, New York, p 123-165

Gasol JM, Vaques D (1993) Lack of coupling between heterotrophic nanoflagellates and bacteria: a general phenomenon across aquatic systems. Limnol Oceanogr 38:657-665 
Gibson JAE, Garrick RC, Burton HR (1990) Seasonal fluctuation of bacterial numbers near the Antarctic continent Proc NIPR Symp Polar Biol 3:16-22

Gonzales JM, Sherr EB, Sherr BF (1990) Size-selective grazing on bacteria by netural assemblages of estuarine flagellates and ciliates. Appl Environ Microbiol 56:583-589

Gonzales JM. Sherr EB, Sherr BF (1993) Differential feeding by marine flagellates on growing versus starving, and on motile versus nonmotile, bacterial prey. Mar Ecol Prog Ser $102: 257-267$

Gonzáles JM. Suttle CA (1993) Grazing by marine nanoflagellates on viruses and virus-sized particles: ingestion and digestion. Mar Ecol Prog Ser 94:1-10

Hodson RE, Azam F, Carlucci AF, Fuhrman JA, Karl DM, Holm-Hansen O (1981) Microbial uptake of dissolved organic matter in McMurdo Sound, Antarctica. Mar Biol 61:89-94

Hondeveld BJM, Bak RPM, van Duyl FC (1992) Bacterivory by heterotrophic nanoflagellates in marine sediments measured by uptake of fluorescently labeled bactena. Mar Ecol Prog Ser 89:63-71

Hunter MD, Price PW (1992) Playing chutes and ladders heterogeneity and the relative roles of bottom-up and topdown forces in natural communities. Ecology 73:724-732

Jørgensen CB (1984) Effect of grazing: metazoan suspension feeders. In: Hobbie JE, Willams PJLeB (eds) Heterotrophic activity in the sea. Plenum Press, New York. p $445-464$

Jürgens K, Güde H (1994) The potential importance of grazing-resistant bacteria in planktonic systems. Mar Ecol Prog Ser 112:169-188

Karl DM (1993) Microbial processes in the Southern Ocean In: Friedmann EI (ed) Antarctıc microbiology. Wiley-Liss New York, p 1-63

King KR, Hollibaugh JT, Azam F (1980) Predator-prey interactions between the larvacean Oikopleura dioica and bac terioplankton in. enclosed water columns. Mar Biol 56 . $49-57$

Kirchman DL, Ducklow HW (1993) Estimating conversion factors for the thymidine and leucine methods for measuring bactenal production. In: Kemp PF, Sherr BF, Sherr EB, Cole JJ (eds) Handbook of methods in aquatic microbial ecology. Lewis, Boca Raton, p 513-517

Kuosa H (1991) Picoplanktonic algae in the northern Baltic Sea: seasonal dynamics and flagellate grazing. Mar Ecol Prog Ser 73:269-276

Kuparinen J, Bjornsen PK (1992) Bottom-up and top-down controls of the microbial food web in the Southern Ocean: expenments with manipulated microcosms. Polar Biol 12 $189-195$

Landry MR (1994) Methods and controls for measuring the grazing impact of planktonic protists. Mar Microb Food Webs 8:37-57

Landry MR, Lehner-Foumler JM, Sundstrom JA, Fagerness $V L$. Selph KE (1991) Discrimination between living and heat-killed prey by a marine zooflagellate, Paraphysomonas vestita [Stokes). J Exp Mar Biol Ecol 146:139-151

Lawrence SG, Ahmad A, Azam F (1993) Fate of particle bound bacteria ingested by Calanus pacificus. Mar Ecol Prog Ser 97:299-307

Leakey RJG, Fenton N, Clarke A (1994) The annual cycle of planktonic ciliates in nearshore waters at Signy Island, Antarctica. J Plankton Res 16:841-856

Lessard EJ (1.991) The trophic role of heterotrophic dinoflagellates in diverse marine environments. Mar Microb Food Webs 5:49-58

Lipski M (1987) Variations of physical conditions, nutrients and chlorophyll a contents in Admiralty Bay (King George Island, South Shetland Islands, 19791. Pol Polar Res 8 $307-332$

Marchant H.J (1985) Choanoflagellates in the Antarctic marine food thain. In: Siegtried WR. Condy PR, Laws RM (eds) Antarctic nutrient cycles and food webs. SpringerVerlag, Berlin, p 271-276

Marchant HJ (1990) Grazing rate and particle size selection by the choanoflagellate Diaphanoeca grandis from the sea-ice of lagoon Saroma Ko, Hokkaido. Proc NIPR Symp Polar Biol 3:1-7

Marchant HJ, Perrin RA (1.990) Seasonal variation in abundance and species composition of choanoflagellates (Acanthoecideae) at Antarctic coastal sites. Polar Biol 10: $499-505$

Marchant HJ, Scott FJ (1993) Uptake of sub-micrometre particles and dissolved organic material by Antarctic choanoflagellates. Mar Ecol Prog Ser 92:59-64

McManus GB, Fuhrman JA (1988a) Clearance of bacteriasized particles by natural populations of nanoplankton in the Chesapeake Bay outflow plume. Mar Ecol Prog Ser 42:199-206

MCManus GB, Fuhrman JA (1988b) Control of marine bacterioplankton populations: measurement and significance of grazing. Hydrobiologia 159:51-62

McManus GB, Okubo A (1991) On the use of surrogate food particles to measure protistan ingestion. Limnol Oceanogr 36:613-617

Monger BC, Landry MR (1992) Size-selective grazing by heterotrophic nanoflagellates: an analysis using livestained bacteria and dual-beam flow cytometry. Arch Hydrobiol Beih Ergeb Limnol 37:173-185

Neuer S, Cowles TJ (1995) Comparative size-specific grazing rates in field populations of ciliates and dinoflagellates. Mar Ecol Prog Ser 125:259-267

Pace ML (1988) Bacterial mortality and the fate of bacterial production. Hydrobiologia 159:41-49

Pace ML, Cole JJ (1994) Comparative and experimental approaches to top-down and bottom-up regulation of bacteria. Microb Ecol 28:181-193

Pedrós-Alió C. Brock TD (1983) The importance of attachment to particles for planktonic bacteria. Arch Hydrobiol Beih Ergeb Limnol 98:354-379

Perrin RA, Lu P, Marchant HJ (1987) Seasonal variation in marine phytoplankton and ice algae at a shallow antarctic coastal site. Hydrobiologia 146:33-46

Peters F (1994) Prediction of planktonic protıstan grazing rates. Limnol Oceanogr 39:195-206

Peters F, Gross T (1994) Increased grazing rates of microplankton in response to s.mall-scale turbulence. Mar Ecol Prog Ser 115:299-307

Porter KG (1988) Phagotrophic phytoflagellates in microbial food webs. Hydrobiologia 159:89-97

Priddle J, Smetacek V, Bathmann U (1992) Antarctic marine primary production, biogeochemical carbon cycles and climate change. Philos Trans R Soc Lond B Biol Sci 338: $289-297$

Rivkin RB (1991) Seasonal patterns of planktonic production in McMurdo Sound, Antarctica. Am Zool 31:5-16

Rivkin RB, Putt M, Alexander SP, Meritt D, Gaudet L (1989) Biomass and production in polar planktonic and sea-ice microbial communities: a comparative study. Mar Biol 101 $273-283$

Sanders RW (1991) Trophic strategies among heterotrophic flagellates. In: Patterson DJ, Larsen J (eds) The biology of free-living heterotrophic flagellates. Clarendon Press, Oxford, p 21-38 
Sanders RW, Caron DA, Berninger UG (1992) Relationships between bacteria and heterotrophic nanoplankton in marine and fresh waters: an inter-ecosystem comparison. Mar Ecol Prog Ser 86:1-14

Sherr EB (1988) Direct use of high molecular weight polysaccharide by heterotrophic flagellates. Nature 335:348-351

Sherr EB, Sherr BF (1993) Protistan grazing rates va uptake of fluorescently labeled prey. In: Kemp PF, Sherr BF, Sherr EB, Cole JJ (eds) Handbook of methods in aquatic microbial ecology. Lewis, Boca Raton, p 695-701

Sherr EB, Sherr BF (1994) Bacternvory and herbivory: key roles of phagotrophic protists in pelagic food webs Microb Ecol 28:223-235

Sherr BF, Sherr EB, McDaniel J (1992) Effect of protistan grazing on the frequency of dividing cells in bacterioplankton assemblages. Appl Environ Microbiol 58:2381-2385

Sherr BF, Sherr EB, Pedrós-Alió C (1989) Simultaneous measurement of bacterioplankton production and protozoan bacterivory in estuarine water. Mar Ecol Prog Ser 54: $209-219$

Sherr BF, Sherr EB, Rassoulzadegan F (1988) Rates of digestion of bacteria by marine phagotrophic protozoa: temperature dependence. Appl Environ Microbiol 54:1091-1095

Shilo M (1984) Bdellovibrio as a predator. In: Klug MJ, Reddy CA (eds) Current perspectives in microbial ecology. American Society for Microbiology, Washington, DC, p 334-339

Sibbald MJ, Albright LJ (1988) Aggregated and free bacteria as food sources for heterotrophic microflagellates. Appl Environ Microbiol 54:613-616

Sieracki ME, Haas LW, Caron DA, Lessard EJ (1987) Effect of fixation on particle retention by microflagellates: underestimation of grazing rates. Mar Ecol Prog Ser 38:251-258

Simon M, Cho BC, Azam F (1992) Significance of bacterial biomass in lakes and the ocean: companson to phytoplankton biomass and biogeochemical implications. Mar Ecol Prog Ser 86:103-110

Smith DC, Steward GF, Azam F (1992) Virus and bacteria abundances in the Drake Passage during January and A.ugust 1991. Antarct J US 27:125-127

Steward GF, Smith DC, Azam F (1996) Abundance and production of bacteria and viruses in the Bering and Chukchi Seas. Mar Ecol Prog Ser 131:287-300

This article was submitted to the editor
Stewart JC, Hawcroft DM (1977) A manual of radiobiology Sidgwick \& Jackson, London

Stoecker DK, Capuzzo JM $\{1990\}$ Predation on protozoa: its importance to zooplankton. J Plankton Res 12:891-908

Sullivan CW, Cota GF, Krempin DW, Smith WO (1990) Distribution and activity of bacterioplankton in the marginal ice zone of the Weddell-Scotia Sea during austral spring. Mar Ecol Prog Ser 63:239-252

Talling JF (1974) General outline of spectrophotometric methods. In: Vollenweider R (ed) A manual on methods for measuring primary production in aquatic environments, IBP Handbook No. 12. Blackwell, Oxford p 22-26

Tobiesen A (1990) Temperature dependent filtration rates and size selection in some heterotrophic microflagellates and one dinoflagellate. Arch Hydrobiol Beih Ergeb Limnol 34: 293-304

Turner JT, Tester PA, Ferguson RL (1988) The marine cladoceran Penilia avirostris and the 'microbial loop' of pelagic food webs. Limnol Oceanogr 33:245-255

Vaqué D, Gasol JM, Marrasé C (1994) Grazing rates on bacteria: the significance of methodology and ecological factors. Mar Ecol Prog Ser 109:263-274

Venrick EL, Beers JR, Heinbokel JF (1977) Possible consequences of containing microplankton for physiological rate measurements. J Exp Mar Biol Ecol 26:55-76

Verity PG (1991) Measurement and simulation of prey uptake by marine planktonic ciliates fed plastidic and aplastidic nanoplankton. Limnol Oceanogr 36:729-750

Verıty PG, Stoecker DK, Sieracki ME, Burkill PH, Edwards ES, Tronzo CR (1993) Abundance, blomass and distribution of heterotrophic dinoflagellates during the North Atlantic spring bloom. Deep Sea Res 40:227-244

Vosjan JH, Olańczuk-Neyman KM (1991) Influence of temperature on respiratory ETS-activity of micro-organisms from Admiralty Bay, King George Island, Antarctica. Neth J Sea Res 28:221-225

Weisse T (1989) The mıcrobial loop in the Red Sea: dynamics of pelagic bacteria and heterotrophic nanoflagellates. Mar Ecol Prog Ser 55:241-250

Wikner J, Rassoulzadegan F, Hagstrom $\AA$ (1990) Periodic bacterivore activity balances bacterial growth in the marine environment. Limnol Oceanogr 35:313-324

Manuscript first received: March 26, 1996

Revised version accepted: July 23, 1996 